\title{
Career fairs: are they valuable events? Hospitality and tourism recruiter perceptions of attributes towards participation and activities
}

\author{
Susan Gordon and Howard Adler* \\ School of Hospitality and Tourism Management, \\ Purdue University, \\ Marriott Hall, West Lafayette, Indiana 47907, USA \\ Fax: 765-494-4643 \\ E-mail: gordon31@purdue.edu \\ E-mail: adlerh@purdue.edu \\ *Corresponding author
}

\section{Sheila Scott-Halsell}

School of Hotel and Restaurant Administration,

Oklahoma State University,

210 Human Sciences Building, Stillwater, Oklahoma 74078, USA

Fax: 405-744-8481

E-mail: sheila.scott-halsell@okstate.edu

\begin{abstract}
The study examined the experience of hospitality and tourism industry recruiters who attended annual university career fairs sponsored by hotel and tourism departments at two major universities. The purpose of the study was to ascertain recruiter perceptions of the value of attending career fairs as a component of their companies' recruiting strategy. Recruiters attending the annual career fairs completed questionnaires. Survey results showed that recruiters perceive that career fairs are important to their companies' recruiting strategies and therefore, a valuable use of their time. Company representatives indicated that the universities were doing a good job in most aspects of the career fair with the exception of having students better prepared for the companies participating.
\end{abstract}

Keywords: campus recruiters; hospitality; recruiter perceptions; career fairs; tourism.

Reference to this paper should be made as follows: Gordon, S., Adler, H. and Scott-Halsell, S. (2014) 'Career fairs: are they valuable events? Hospitality and tourism recruiter perceptions of attributes towards participation and activities', Int. J. Hospitality and Event Management, Vol. 1, No. 1, pp.81-94.

Biographical notes: Susan Gordon is a $\mathrm{PhD}$ student and graduate research assistant at the School of Hospitality and Tourism Management, Purdue University. She received her Masters in Business Administration from Boston University and also holds a Bachelor of Science in Hospitality Administration from the University of Massachusetts at Amherst. Her industry work experience spans over ten years and includes management positions with Starwood Hotels and Resorts, Marriott International, Inc., and Walt Disney World. Her research interests include human resources and lodging operations. 
Howard Adler has been a faculty member at Purdue University since 1982 teaching primarily in the area of hotel operations. He has held several management positions in the hotel industry including General Manager with Sheraton as well as Director of Sales, Front Office Manager and Resident Manager with some private resorts. He spent the 1999/2000 school year teaching at the University Del Este, in San Juan, Puerto Rico and the 2006/2007 school year teaching at the South China University of Technology in Guangzhou, China and the Macau Institute of Tourism, Macau, China.

Sheila Scott-Halsell is an Associate Professor and Associate Director of the School of Hotel and Restaurant Administration at Oklahoma State University. She is also the co-Director of the US-EU FIPSE HOTEL Atlantis Dual Degree Program. Before joining OSU in 2006, she received her PhD from Texas Tech University. Spending 17 years in hospitality management roles, prior to returning for graduate studies, strongly influences her research areas of human resources, organisational behaviour and event management. Her grant activities, as PI or co-PI, total $\$ 501,607.23$.

\section{Introduction}

Career fairs held on university campuses are one way for companies to meet recruiting goals, especially given the competition to attract the best talent (Silkes et al., 2010). Career fairs also allow students to learn about organisations and their recruiting needs (Brennan et al., 2004). There has been research about recruiters' behaviours and their effect on students (Wildes and Tepeci 2003), but no studies exist about recruiters' perceptions of the value in attending university career fairs. According to Chi and Gursoy (2009), the success of career services depends on the relationship that universities have with industry partners and, therefore, "it is important to explore factors that are likely to influence the success of the career services provided by hospitality programs" (p.309). Career fairs are a component of university career services, but since no research currently exists concerning recruiters' perceptions of career fairs, the present study is relevant to the success of university career services. Companies spend large amounts of money on recruiting, of which career fairs are a component, in order to secure future employees (Tepeci and Wildes, 2002). If recruiters do not feel that their time is well spent at career fairs, they may choose not to attend them. There are over 200 hospitality and tourism programs at universities in the USA (Crawford et al., 2009) so part of determining from where to recruit is based on university career fairs. Because of this, universities must provide effective career fairs as they cannot rely solely on their hospitality department's reputation to attract companies (Chi and Gursoy, 2009).

The purpose of the present research was to augment research about university recruiting and provide information to university career services on how recruiters from the hospitality and tourism industry perceive university career fairs. Specifically, the study attempted to reveal aspects of career fairs that recruiters found useful as well as any changes in career fairs that recruiters determined would strengthen the career fair experience. It is expected that universities will use the findings to make improvements to career fairs so companies will continue to attend them to recruit high quality candidates for positions. The study looked at the experiences of recruiters from hospitality 
companies who attended career fairs held by two major hospitality and tourism programs. The following research questions were answered in the study.

- What is the demographic profile of individuals who recruit at hospitality career fairs?

- Do recruiters feel that their attendance at career fairs is beneficial to their companies?

- Do recruiters feel that career fair facilities serve their requirements?

- Do recruiters feel that the students are well prepared?

- What aspects of career fairs would recruiters change?

\section{Literature review}

\subsection{Company recruiting strategy}

Companies use career fairs as a means to find candidates with a balance of work and academic experience while also reducing the time it takes to fill positions (Hansen, 2006). In turn, career fairs allow students to learn about different companies and assess their fit with the organisation (Silkes et al., 2010). Another advantage of career fairs is that they allow students to learn about careers and career paths within an industry that they may not have realised existed prior to the fair (Payne and Sumter, 2005). Through these fairs, companies can establish contact with students and fill internships in addition to hiring graduating students for permanent positions (Hansen, 2006). Students benefit from a large number of companies gathering in the same location and companies benefit because they are able to access a large number of students during one visit (Payne and Sumter, 2005).

Recruitment of college students typically is conducted in cycles, which means that it is easier for a company to employ a planned strategy for this type of recruiting (Rynes and Boudreau, 1986). One study found that $66 \%$ of companies reevaluate college visit selections annually, which results in about $14 \%$ of companies adding campuses and $20 \%$ of companies dropping campuses (Rynes and Boudreau, 1986). The study found that the primary reasons for dropping campuses were lack of success in finding candidates, low job acceptance rates, and reductions in company recruiting expenses (Rynes and Boudreau, 1986). This may be especially crucial information for universities given the current economy and the fluctuation in college visits by companies. For many organisations, college recruiting can represent a large portion of their human resources budgets. The estimated average cost was $16 \%$ of the human resource budgets for Fortune 500 companies (Stevens, 1997). Most of the money was spent on recruiters' salaries and travel expenses (Stevens, 1997). In addition, if the company selects the wrong candidate into an entry-level management position, turnover can cost the company $\$ 50,000$ or more (Tepeci and Wildes, 2002). Therefore, spending money to attend a career fair to find the 'best fit' candidates can be money well spent. One recruiter stated that spending money 
on career fairs overall is well worth the effort given the amount of exposure a company can obtain and the number of people it can reach (Hansen, 2006).

Companies also utilise online job fairs as a way to reach candidates and some smaller universities also utilise this format (Zelenskaya and Singh, 2011). Some companies have taken the online job fairs one step further by employing virtual programs that allow the recruiter and applicant to interact and conduct interviews in an online world (Zelenskaya and Singh, 2011). Because many companies do recruit online, companies have found that the combination of fairs and technology strengthens their recruiting strategies as fairs allow them 'face' time with quality candidates (Hansen, 2006). College recruitment involves a presence on college campuses including sponsoring events, giving company presentations, speaking at student organisations, and attending career fairs. A presence on campus is a tool to attract entry-level managers (Tepeci and Wildes, 2002). An on-campus interview is typically the first face-to-face contact between a recruiter and a student (Powell and Goulet, 1996). Interacting with a recruiter at a career fair is a way for students to meet the recruiter prior to the interview and, hopefully, make a more meaningful impression. However, companies must be careful not to become overexposed on campus. One study found that on-campus presence did not correlate with intention or behaviour to pursue positions at the company, suggesting that overexposure can cause perceptions of distrust and lowered credibility (Jaidi et al., 2011).

\subsection{Recruitment of hospitality students}

Throughout the last two decades, companies have implemented extensive on-campus recruiting processes to fill a growing skills shortage with qualified candidates (Miranda, 1999). Some companies may be on-campus year round as part of their corporate recruiting strategies (Chi and Gursoy, 2009). Hospitality schools have seen an increase in the number of companies attending their career fairs (Crawford et al., 2009). In addition, as the number of hospitality programs continues to increase (currently over 200 within the USA), the candidate pool will increase (Crawford et al., 2009). Hospitality recruiters are looking for candidates who have both industry skills and academic qualifications (Chi and Gursoy, 2009). In a recent study of hospitality recruiters of college graduates, the top five factors that recruiters in the hospitality industry are seeking when they visit a college campus were determined to be: "(1) how students prepare themselves for the real world (via internships), (2) level of faculty industry experience, (3) the quality of students' preparation for interviews for full-time jobs and internships, (4) reputation of the hospitality program, and (5) the quality of students' educational curriculum and courses taught in hospitality/tourism management" [Chi and Gursoy, (2009), p.314].

Some of the factors that influence hiring of hospitality graduates include: "student characteristics, recruiting-selection process, recruiters' demographic backgrounds, and their expectations" [Kwok et al., (2011), p.375]. The main criteria used by recruiters are student characteristics encompassing intellectual abilities, grade point average or academic accomplishments, work and internship experience, and activities outside of school such as clubs and sports (Kwok et al., 2011). In a study by Kwok et al. (2011) of hospitality recruiters, other factors found to influence the hiring of hospitality students were personality, flexibility, leadership skills, and soft skills. When asked to rank the items most important in recruitment of hospitality students, leadership, relevant job experience, and person-organisation and person-job fit tied for the top item with personality ranked second (Kwok et al., 2011). 


\subsection{Recruiter profile}

The population and experience of college recruiters varies and companies utilise different strategies to select who will visit college campuses (Harris et al., 2006). Recruiters may be recent college graduates who may relate better to students, seasoned managers to whom the new hires will report, or human resource directors (Harris et al., 2006). One study found that criteria for recruiters that were rated as important included: "(1) strong interpersonal skills, (2) enthusiasm for the company, (3) knowledge of company and jobs, and (4) credibility with students and co-workers" [Rynes and Boudreau, (1986), pp.740-741]. While the criteria of the recruiter seem to be important to companies, training does not draw the same interest. That study also found that only $41 \%$ of the companies surveyed offered standardised training programs, and only $48 \%$ required the training of recruiters (Rynes and Boudreau, 1986).

Companies send between one and five people to career fairs for an average of two days. These recruiters typically either work in human resources or operations (Silkes et al., 2010). The position that the recruiter holds within the company varies from company to company, but one effective method is to use employees within a university's geographic region as these employees can conduct on-site interviews at the school as well as establish ongoing relationships (Morley, 2001). Companies also send recent graduates to career fairs at the universities they attended because these employees already have connections with current students which may lead to a connection for the whole company (Hansen, 2006). Some companies have found that paying a stipend to a former intern to become a campus representative upon his return to school is also an effective way to increase awareness of the company (Hansen, 2006). Sending employees to career fairs not only increases employee morale, but it can also turn employees into year-round recruiters (Hansen, 2006). Another advantage of career fairs is the ability of employers to observe the competition, especially when attending industry-specific fairs.

\subsection{Student perceptions of recruiters and companies}

Career fairs provide recruiting opportunities, but they also allow companies an opportunity to increase brand awareness (Hansen, 2006). This is an important opportunity because some students only know about the company through the recruiter (Silkes et al., 2010). Applicants are influenced by "(1) how amiable, empathetic, caring, concerned, and how knowledgeable a recruiter is about the company, (2) its positions, and (3) its applicants" [Silkes et al., (2010)0, p.121]. In addition, research has shown that the impressions applicants have of the recruiters affect how applicants approach the recruiting process, including their decision about job selection (Connerley and Rynes, 1997). One study found that likability of hosts from the company that assisted students during site visits to potential employers explained the variance in job offer decisions (Turban et al., 1995). How the candidate feels about the host and those companies reflects that company representatives need to be selected carefully; (Turban et al., 1995), the same care needs to be taken of recruiters attending a career fair.

Signalling theory is one explanation of applicant job decisions since experiences with recruiters can serve as major, but unobservable, signals of organisational characteristics (Connerley and Rynes, 1997). For example, "interviewees interpret recruiters' interpersonal effectiveness (e.g., non-verbal cues, symbols, friendliness, organisational skills, and verbal behaviour) as signals of organisational effectiveness" 
[Wildes and Tepeci, (2003), p.41]. Prior studies have shown that the amount of information provided to candidates positively affects the attractiveness of the company as a place to work (Turban et al., 1995). In addition, students may perceive the absence of information as a signal that the company does not care enough to provide them with accurate information. Because research has shown that there is a strong relationship between applicant impressions during the early stages of recruiting and final decisions, impressions that recruiters make on applicants are of key importance (Connerley and Rynes, 1997). One major study found that one third of the students interviewed stated that the main reason they accepted the job offer was because of their interaction with the recruiter (Rynes and Miller, 1983).

\subsection{Recruiter-educator relationships}

Work expectations are ever-changing and recruiters are the connection between education and industry (Miranda, 1999). One of the ways students benefit from the relationship between recruiters and educators is that recruiters can give advice about which courses students should take to better prepare themselves for the area in which they are specialising (Payne and Sumter, 2005). Educators also need to keep up with industry changes in order to ensure that students are well prepared for future positions (Miranda, 1999). One way this is accomplished is through career fairs and relationships that are built between universities and recruiters. Often department-run career fairs are organised by students, allowing them to better learn about the industry they will be entering (Payne and Sumter, 2005). Students should work with professors to reach out to their industry contacts to produce a quality career fair. In addition, internship and job opportunities for students strengthen the recruiter-educator relationship. It often leads to other partnerships such as research as well as increasing both the school's profile and company's profile in the minds of students (Chi and Gursoy, 2009). These opportunities lead to long-term relationships that will continue to optimise benefits for students in the future.

\section{Methodology}

\subsection{Instrument design}

After a thorough review of the literature, no other study had been conducted about recruiter perspectives of career fairs. A focus group was held with recruiters at a large Midwestern university regarding issues of concern about career fairs. Results of the focus group and related industry literature review were used to develop a survey with questions about recruiter experiences at career fairs. In addition, various demographic questions were posed. The survey was divided into three sections and used various scales to measure responses.

The first section of the survey asked recruiters questions about their basic information, which included:

1 whether they were a graduate of a hospitality and tourism management (HTM) program

2 their title 
3 number of times they had attended the particular career fair at which they received the survey

4 average number of days they spend per year at career fairs

5 average number of career fairs attended

6 number of people sent to a career fair by their company

7 if interviews are conducted while at the career fair

8 are the interviews for internships, graduating students, or both.

This section also asked recruiters about their companies' recent hiring of college graduates in terms of how it has changed during the previous year. Recruiters were asked if they were looking for the same or different number of students and if the number of university career fairs they attended had changed.

The second section of the survey asked about the value of career fairs as a recruiting tool for their companies and their opinions on the format of career fairs. Recruiters were asked to rate the value that they placed on attending hospitality career fairs as well as the main purpose of attending them. The questions were developed from the 2006 study conducted by Harris et al.

In the third section, recruiters were asked what they liked best about career fairs related to such activities as:

1 keynote speakers

2 evening receptions

3 lunch with students

4 interviewing while at the fair

5 interacting with other recruiters

6 interacting with students.

These questions were developed based on the 2009 article by Harrison et al. The final question was designed to solicit possible changes recruiters may suggest regarding career fairs including:

1 length of time

2 attendance regulated by student class (freshman, sophomore, junior, and senior)

3 size of booth

4 number of students in attendance.

\subsection{Data collection and analysis}

The present study focused on recruiters who attended annual HTM program career fairs held at two large Mid western universities. Recruiters who attended the two career fairs were surveyed regarding their perceptions of career fairs in general and the effectiveness of career fairs as a tool to meet their companies' recruiting needs. Those recruiters primarily were human resource and operations professionals from a total of 68 different 
hospitality companies. Among the companies represented at the fairs, 32 were classified in the lodging sector, 29 were classified as foodservice or restaurant operations, four were classified as tourism related, two companies were in the foodservice equipment sector, and the last one was in hospital management. Many of the companies had more than one person from their organisation attending. The population of recruiters for the two career fairs was 125. The research was conducted during the fall of 2010 and spring of 2011. These particular career fairs are held once per year as opposed to some universities which hold career fairs during both semesters. One university held its career fair in the fall and the other one held its event during the spring for three hours in the afternoon. All students within the hospitality and tourism departments were invited to attend. A reception for the recruiters was held the evening prior to each career fair with the hospitality faculty and graduating seniors invited to meet recruiters.

The survey was distributed to recruiters during the reception the evening prior to the career fair. The survey included a letter that advised the participants of the purpose of the research and assured them of confidentiality and anonymity of their responses. The letter also provided participants with the researchers' names and contact information. Those recruiters who did not attend the reception were given the letter and survey the following day during the career fair. Completed surveys were collected during the fair; those recruiters who were unable to complete the survey during the career fair returned their responses by postage paid envelopes. The research was conducted independently from any participating companies, although results are available by request from participating companies. Survey data was entered into an Excel database for quantitative analysis.

\section{Results and discussion}

Findings of the survey related to recruiter perceptions and answered the research objectives. Do recruiters feel that career fairs are valuable, what are the most important activities they value as part of the career fair such as networking, and interviewing, and do HTM programs facilitate these activities? If they do not find the career fair valuable, what can HTM programs do to change that perception as they should not rely simply on the department or university's reputation to attract recruiters (Chi and Gursoy, 2009). Such information will allow HTM programs to change the format or activities of career fairs to better accommodate recruiter attendees in the future.

\subsection{Recruiter and company demographics}

A total of 125 surveys were distributed to recruiters; 76 were returned for a response rate of $61 \%$. Of those who responded, $50 \%$ were male, $34 \%$ were female, and $16 \%$ did not provide their gender. The majority of respondents were from hotel companies at $49 \%$ of the total, followed by restaurants at $38 \%$, and others including healthcare, suppliers, convention bureaus, and retail at $13 \%$. In terms of the positions held by recruiters, human resource individuals accounted for $57 \%$ of the respondents, operations accounted for $39 \%$, and $4 \%$ of respondents did not give their job title. Only $42 \%$ of the respondents were graduates of a hospitality program, while $58 \%$ had other majors.

Recruiters were asked how many times they had attended the particular career fair, including the current visit. Of the 76 respondents, 33\% were attending the fair for the first 
time, $17 \%$ for the second time, $20 \%$ for the third time, $27 \%$ for the fourth time or more, and $3 \%$ did not respond to the question. Recruiters also were asked the average number of days they spend at a university when attending a career fair. The majority (61\%) indicated they spend two to three days, $36 \%$ indicated one day, and 3\% did not respond to the question. When asked the average number of people sent to the career fair by the companies, $11 \%$ indicated one person, $43 \%$ indicated two people, $33 \%$ indicated three people, $11 \%$ indicated four people, and $2 \%$ did not respond. Recruiters were then asked how many career fairs at other universities they attend per year. Of the 76 respondents, $20 \%$ responded that this was their only career fair, $14 \%$ attended one other career fair, $24 \%$ attended two or three other career fairs, $24 \%$ attended between four and nine other career fairs, $14 \%$ attended ten or more other career fairs, and $4 \%$ did not respond to the question.

Almost three-fourths $(71 \%)$ of the respondents indicated they were also conducting interviews while they were on campus. Of the 54 respondents who were interviewing, nine were interviewing only for internships and no May graduates, three were allocating $10 \%$ or less of their interviews for May graduates and the rest were for internships, four were allocating $20 \%$ to $30 \%$ for May graduates, 19 were splitting the interviews at $50 \%$ for May graduates and $50 \%$ for internships, 13 were allocating $60 \%$ to $95 \%$ for May graduates, four were dedicating all interviews for May graduates, and two recruiters did not respond.

In terms of their recruiting efforts during the last year, $47 \%$ of the respondents reported their company was visiting the same number of schools as the previous year, while $36 \%$ reported their company was visiting more schools, and $17 \%$ reported that their company was visiting fewer schools. Compared to the previous year, $31 \%$ of the recruiters indicated that their company was hiring more graduates, $47 \%$ stated their company was hiring the same number of graduates, and $22 \%$ stated their company was hiring fewer graduates.

\subsection{Career fair value}

Regarding value, recruiters were asked if they felt that career fairs are an important component of their company's recruiting strategy. The mean response was 4.5 on a scale of 1 to 5, with the higher number indicating very important. Recruiters believed that attending career fairs on behalf of their company is an important function. Recruiters also were asked if they felt that career fairs are mainly a public relations (PR) function for a company. Recruiters averaged a 3.07 response on a scale of 1 to 5 , indicating that some feel that it is simply a PR function to keep a company's name relevant while some do not hold that belief. Possibly while some recruiters agreed that career fairs only serve a PR function, they did not see this as a negative aspect in terms of recruiting, especially given that many of the companies are not currently in a position to hire numerous people. When asked if recruiters felt that career fairs are a good use of company time and a way to make the company better known, the mean response was 4.39 on a scale of 1 to 5 . When asked about student preparedness, recruiters felt that students were well prepared to represent themselves to companies as indicated by the mean response of 4.13 on a scale of 1 to 5 . Table 1 addresses recruiter perceptions of career fair value. 
Table 1 Recruiter perceptions of career fair value

\begin{tabular}{lc}
\hline \multicolumn{2}{c}{ Perceptions of career fair value } \\
\hline \multicolumn{2}{c}{ Mean response } \\
\hline Important component to recruiting strategy & 4.50 \\
Help make company become better known & 4.39 \\
Happy with career fair format & 4.28 \\
Student were prepared & 4.13 \\
Public relations activity for company & 3.07 \\
\hline
\end{tabular}

\subsection{Career fair environment}

The researchers asked about career fair facilities. The majority of recruiters felt that the facilities of the career fairs met their needs. The mean response was 4.38 on a scale of 1 to 5 , with 1 as strongly disagree and 5 as strongly agree. Regarding the format of career fairs, the mean response was 4.28 on a scale of 1 to 5 , indicating that overall recruiters were satisfied with how the two schools run their career fairs. Only $36 \%$ of the recruiters indicated that they would change some aspect of the career fairs. Among the 27 who indicated they would make changes, 17 selected regulating attendance by class (freshman, sophomore, junior, and senior), as the most popular answer followed by a desire to have a longer career fair as indicated by $15 \%$. A few respondents wrote in their own suggestions. Some of the comments were "more time to interview, one hour not 30 minutes", "more attendance by students", "more interaction with university faculty", "each company [makes] a presentation and/or small group panel discussions", and "have [company]information session prior to career day". Table 2 shows recruiter preferences for changes to career fair formats.

Table 2 Recruiter preferences for changes to career fair formats

\begin{tabular}{lcc}
\hline \multicolumn{3}{c}{ Perceptions of format changes } \\
\hline Frequency $n=27$ & Percent \\
\hline Regulate attendance & 17 & $63 \%$ \\
Longer career fair & 4 & $15 \%$ \\
Shorter career fair & 3 & $11 \%$ \\
Larger booths & 3 & $11 \%$ \\
Less crowded & 0 & $0 \%$ \\
\hline
\end{tabular}

\subsection{Career fair activities}

In the third section of the survey, recruiters were asked to rank the top two activities they deemed most useful during the career fair. The majority selected interacting with students as their first choice and being able to interview students as their second choice. The responses demonstrated that recruiters' main objective in attending career fairs was to interact with the students, both at the career fair itself and while interviewing. Table 3 shows recruiter perceptions of career fair activities. 
Table 3 Perceptions of career fair activities

\begin{tabular}{lccccc}
\hline \multicolumn{5}{c}{ Perception of career fair activities } \\
\hline & \multicolumn{4}{c}{ Frequency $n=66$} \\
\cline { 2 - 4 } & First choice & Percent & & Second choice & Percent \\
\cline { 2 - 3 } \cline { 5 - 6 } Interact with students & 47 & $71 \%$ & & 12 & $18 \%$ \\
Time to interview & 13 & $20 \%$ & & 30 & $45 \%$ \\
Keynote speakers & 5 & $8 \%$ & & 3 & $5 \%$ \\
Evening receptions & 1 & $2 \%$ & & 7 & $11 \%$ \\
Lunch with students & 0 & $0 \%$ & 7 & $11 \%$ \\
Interact with recruiters & 0 & $0 \%$ & 7 & $11 \%$ \\
\hline
\end{tabular}

\section{Conclusions and recommendations}

Many university hospitality programs have their own career centres to aid students in securing internships and jobs upon graduation (Chi and Gursoy, 2009). Career fairs typically are a component of these career services. Career fairs are a tool commonly employed by various university departments to showcase their students. At the same time, companies are able to go to the career fair and use the advantage of a large number of students to meet their future workforce needs. Because recruiters are vital to the success of student recruiting and career fairs, understanding recruiter perceptions of career fairs is important in order to ensure they attend them. If companies send recruiters to career fairs, then students may perceive that the company places value on the career fair and the students who attend them (Rynes et al., 1980). If companies understand that students have a better perception of them due to their career fair participation and attend career fairs due to company participation, then companies will be more apt to continue to attend career fairs. The perceptions of recruiters about career fairs is also crucial to the administration of hospitality departments as placement rates, location, and position can help attract future applicants to the school (Kwok et al., 2011). In terms of academic contributions, while research has been conducted about students' perceptions of career fairs (Silkes et al., 2010), to the authors' knowledge, recruiters' perceptions of career fairs have not been studied previously. Therefore, the present study adds to research about university recruiting by evaluating the perceptions of recruiters at career fairs.

One of the recruiting strategies that companies utilise in college recruiting is to send operations managers to career fairs within their geographic area (Morley, 2001). Another interesting finding from the career fair survey was that of the 26 recruiters who do not attend another career fair or only attend one other career fair, only four of those respondents were in human resources. By comparison, of the 29 respondents who attend four or more other career fairs, only two of them were from operations. Such findings would suggest that hospitality and tourism companies are utilising the strategy of sending 
operations managers to some career fairs within their local area, while others send human resource managers to several career fairs regardless of location. This result is also consistent with the findings in the previous study (Silkes et al., 2010) that recruiters typically either work in human resources or operations.

The study found that $87 \%$ of the respondents indicated that their company sends more than one person to a university career fair. In addition, $61 \%$ of the respondents were spending two or three days on campus to attend the career fairs and recruits either before or afterwards. The findings were also evident in the previous literature (e.g., Silkes et al., 2010). The present study suggests that universities need to be aware of the number of days recruiters are spending on campus and take advantage of it. For example, more opportunities for partnerships with faculty that go beyond speaking in the classrooms can be developed, such as consulting work that may also produce increased research.

Since recruiters indicated what they enjoyed most about career fairs was interacting with students, hospitality and tourism programs could develop additional opportunities such as forums or panels of recruiters. Commonly practiced, recruiters appear in the classroom, but this often takes a more formal approach. In addition, students often voice the desire to have more informal interaction with company recruiters to learn more about the industry and the successful career paths of the recruiters themselves who often are engaged in higher-level management. This could be accomplished through inviting companies to sponsor school events or asking them to speak at student clubs, which also benefits companies since it allows them to establish an on-campus presence (Tepeci and Wildes, 2002). Only one respondent indicated that interacting with other recruiters was an aspect he or she liked best; recruiters are more focused on students than they are with networking among their peers during career fairs. Therefore, universities would do well to increase the opportunities for student-recruiter and faculty-recruiter interaction rather than trying to increase networking for recruiters.

Another comment related to the time spent on interviews. Recruiters would like to extend the timeframe for each interview. Both students and recruiters would benefit; however it would be necessary for companies to extend the amount of time that they spend at each school or send more recruiters. This is often not feasible due to budget and time constraints as travel expenses comprise a large amount of companies' human resource budget (Stevens, 1997).

While career fairs are an important part of many companies' recruiting efforts, tight human resource budgets often call for companies to be very selective in the number of schools they visit. A reduction in recruiting expenditures is one of the reasons companies decide not to continue visiting a campus (Rynes and Boudreau, 1986). Another reason for no longer going to a university is lack of ability to find the right candidates (Rynes and Boudreau, 1986). Some of the recruiters' comments pertaining to the students were "students should research [the] company before the fair", "higher student attendance", and "survey students as to what they are looking for in a company and why they select one over another". Such comments suggest that universities could do a better job of encouraging students to not only attend the fair, but to research the companies before speaking with recruiters. Because industry experience is important to hospitality and tourism industry recruiters, educators must continue to ensure that students are prepared for the career fair to secure internships and permanent jobs. In addition, the students' preparation reflects on the university; so students must present themselves well when interacting with recruiters. 


\section{Limitations and recommendations for future research}

The study represented only two career fairs at two universities. While the study was representative of the recruiters who attended the career fairs at the universities where the study was conducted, the possibility exists for differences with other similar programs and fairs based on the type of department in which the program is housed, the university's size, location of the university, and others. However, both of the programs have been in existence for over 50 years, are ranked in the top 10 among hospitality programs (Severt et al., 2009), and hold career fairs which are heavily attended by major companies in the hospitality industry. Therefore, these programs are viewed as highly generalisable within the hospitality program university setting. One of the career fairs was held in the fall and the other university held its event in the spring, so there may be additional differences based on this fact. In the fall, sometimes recruiters do not interview during the career fair and choose to return to campus during the spring to interview. Also during the spring, students who have not yet found employment may tend to be more aggressive with the time that they spend with recruiters. These factors may affect recruiter attitudes. Future research could study the differences in recruiters' perceptions of career fairs based on time of year held or differences in recruiting efforts in terms of types of interviews conducted (internships or May graduates). In addition, future research could focus on the success that companies have had with the students they recruited through career fairs over time.

\section{References}

Brennan, C., Daly, M., Fitzpatrick, E. and Sweeney, E. (2004) 'Tradition vs. technology: career fairs in the 21st century', International Journal for Educational and Vocational Guidance, Vol. 4, No. 1, pp.23-41.

Chi, C. and Gursoy, D. (2009) 'How to help your graduates secure better jobs? An industry perspective', International Journal of Contemporary Hospitality Management, Vol. 21, No. 3 , pp.308-322.

Connerley, M. and Rynes, S. (1997) 'The influence of recruiter characteristics and organizational recruitment support on perceived recruiter effectiveness: views from applicants and recruiters', Human Relations, Vol. 50, No. 12, pp.1563-1586.

Crawford, A., Hubbard, S., Gaillard, N. and Waln, M. (2009) 'Strategies for on-campus recruitment: a decade later', Consortium Journal of Hospitality \& Tourism, Vol. 13, No. 2, pp.5-13.

Hansen, F. (2006) 'Far from obsolete, career fairs are a low-cost way for firms to hire quickly and fill pipelines', Workforce Management, Vol. 85, No. 4, pp.46-47.

Harris, K., Kwansa, F. and Lattuca, F. (2006) 'Recruiter opinion of hospitality programs: an assessment of selected programs', Journal of Human Resources in Hospitality \& Tourism, Vol. 5, No. 1, pp.17-31.

Harrison, K., Kerby, D. and Fleak, S.K. (2009) 'Foraging effective campus relationships', The CPA Journal, Vol. 79, No. 1, pp.69-71.

Jaidi, Y., Van Hooft, E. and Arends, L. (2011) 'Recruiting highly educated graduates: a study on the relationship between recruitment information sources, the theory of planned behavior, and actual job pursuit', Human Performance, Vol. 24, No. 2, pp.135-157. 
Kwok, L., Adams, C.R. and Price, M.A. (2011) 'Factors influencing hospitality recruiters' hiring decisions in college recruiting', Journal Of Human Resources In Hospitality \&Tourism, Vol. 10, No. 4, pp.372-399.

Miranda, P. (1999) 'The Level of technical skills and management competency demanded by the hospitality industry as perceived by hospitality recruiters', Unpublished master's thesis. University of Wisconsin-Stout, Menomonie, WI, retrieved September 6, 2010 from Dissertations and Theses database.

Morley, M. (2001) 'Opening the window of job opportunity', Lodging Hospitality, Vol. 57, No. 11, p.28.

Payne, B. and Sumter, M. (2005) 'College students' perceptions about career fairs: what they like, what they gain, and what they want to see', College Student Journal, Vol. 39, No. 2, pp.269-276.

Powell, G. and Goulet, L. (1996) 'Recruiters' and applicants' reactions to campus interviews and employment decisions', Academy of Management Journal, Vol. 39, No. 6, pp.1619-1640.

Rynes, S. and Boudreau, J. (1986) 'College recruiting in large organizations: practice, evaluation, and research implications', Personnel Psychology, Vol. 39, No. 4, pp.729-757.

Rynes, S. and Miller, H. (1983) 'Recruiter and job influences on candidates for employment', Journal of Applied Psychology, Vol. 68, No. 1, pp.147-154.

Rynes, S., Heneman, H.G. and Schwab, D.P. (1980) 'Individual reactions to organization recruiting, a review', Personnel Psychology, Vol. 33, No. 3, pp.529-542.

Severt, D.E., Tesone, D.V., Bottorff, T.J. and Carpenter, M.L. (2009) 'A world ranking of the top 100 hospitality and tourism programs', Journal of Hospitality \& Tourism Research, Vol. 33, No. 4, pp.451-470.

Silkes, C., Adler, H. and Phillips, P.S. (2010) 'Hospitality career fairs: student perceptions of value and usefulness', Journal of Human Resources in Hospitality \& Tourism, Vol. 9, No. 2, pp.117-130.

Stevens, C. (1997) 'Effects of preinterview beliefs on applicants' reactions to campus interviews', Academy of Management Journal, Vol. 40, No. 4, pp.947-966.

Tepeci, M. and Wildes, V. (2002) 'Recruiting the best: a study in attracting hospitality management students for entry-level management positions', Journal of Quality Assurance in Hospitality \& Tourism, Vol. 3, Nos. 1-2, pp.95-107.

Turban, D., Campion, J. and Eyring, A. (1995) 'Factors related to job acceptance decisions of college recruits', Journal of Vocational Behavior, Vol. 47, No. 2, pp.193-213.

Wildes, V. and Tepeci, M. (2003) 'Influences of campus recruiting on applicant attraction to hospitality companies', Journal of Human Resources in Hospitality \& Tourism, Vol. 2, No. 1, pp.39-51.

Zelenskaya, K. and Singh, N. (2011) 'Exploring virtual recruiting from employers' perspective using 'Second Life", Journal of Human Resources in Hospitality \& Tourism, Vol. 10, No. 2 , pp.117-128. 